\title{
PENINGKATAN PENDAPATAN MASYARAKAT MELALUI DIVERSIFIKASI OLAHAN TAPE SINGKONG
}

\author{
Increasing Community Revenues Through Diversification of Cassava Tape Processing \\ Deny Utomo $^{1)}$,Cahyuni Novia ${ }^{2)}$, Syaiful ${ }^{2)}$, M. Syafiih ${ }^{2)}$, \\ ${ }^{1}$ Fakultas Pertanian, Universitas Yudharta Pasuruan \\ ${ }^{2}$ Fakultas teknik, Universitas Nurul Jadid Probolinggo \\ Penulis korespondensi, email : denyut369@yudharta.ac.id
}

\begin{abstract}
Karanganyar Village is a village located in Paiton Sub-district of Probolinggo Regency of East Java Province. The inhabitants are mostly farmers and some are traders. Traders who currently provide an attraction for local residents is selling yellow cassava tape. The average sales of tape in these traders is about 5 tons per day. The goal to be achieved in community service activities is to increase the income of the community groups of PKK mothers through the processing of various processed cassava tape into chips, dodol, and cake. The method is done by using lecture and demonstration method along with training materials, and delivered directly by performing a presentation related to the process of making chips, dodol, and cake ranging from raw materials, how to use the tools of production, the process of mixing the materials, cooking until packaging. The results of the whole 100\% of partners can make a variety of processed cassava tape and can do the packaging well.
\end{abstract}

Keywords: Cassava tape, chips, dodol, cake

\begin{abstract}
ABSTRAK
Desa Karanganyar adalah sebuah desa yang terletak di Kecamatan Paiton Kabupaten Probolinggo Propinsi Jawa Timur. Penduduknya sebagian besar berprofesi menjadi petani dan sebagian lainnya menjadi pedagang. Pedagang yang saat ini memberikan daya tarik bagi warga setempat adalah berjualan tape singkong warna kuning. Rata-rata penjualan tape di para pedagang ini sekitar 5 ton per hari. Tujuan yang ingin dicapai dalam kegiatan pengabdian kepada masyarakat ini adalah meningkatkan pendapatan masyarakat kelompok ibu-ibu PKK melalui pengolahan aneka olahan tape singkong menjadi keripik, dodol, dan cake. Metode yang dilakukan dengan menggunakan metode ceramah dan demonstrasi disertai materi pelatihan, serta disampaikan langsung dengan melakukan pendemontrasian yang berkenaan dengan proses pembuatan keripik, dodol, dan cake mulai daripenanganan bahan baku, cara penggunaan alatalat produksi, proses pencampuran bahan, pemasakan sampai pengemasan. Hasil secara keseluruahan hampir 100\% mitra kerja dapat membuat aneka olahan tape singkong serta dapat melakukan pengemasan dengan baik.
\end{abstract}

Kata kunci : Tape singkong, keripik, dodol, cake

\section{PENDAHULUAN}

Desa Karanganyar adalah sebuah desa yang terletak di Kecamatan Paiton Kabupaten Probolinggo Propinsi Jawa Timur. Penduduknya sebagian besar berprofesi menjadi petani dan sebagian lainnya menjadi pedagang. Pedagang yang saat ini memberikan daya tarik bagi warga setempat adalah berjualan tape singkong warna kuning. Peluang tambahan pendapatan yang lumayan besar dari berdagang tape, karena tempat berjualannya yang sangat strategi, yaitu dekat pondok 
pesantren Nurul Jadid, sekolah (SD, SMP, SMA), pasar, dan pinggir jalan raya Provinsi Jawa timur yang menuju kearah pulau Bali. Rata-rata penjualan tape di para pedagang ini sekitar 5 ton per hari..

Tape adalah produk yang dihasilkan dari proses fermentasi, di mana terjadi suatu perombakan bahan-bahan yang tidak sederhana. Zat pati yang ada dalam bahan makanan diubah menjadi bentuk yang sederhana yaitu gula, dengan bantuan suatu mikroorganisme yang disebut ragi atau khamir (Hasanah et al., 2013).Kelebihan produk fermentasi dibandingkan dengan olahan lainnya diantaranya adalah mudah dicerna,cita rasa lebih enak dan nilai nutrisi (Parwiroharsono, 2007). Tape yang sering dikembangkan di Indonesia adalah jenis tape singkong dan tape ketan.

Tape singkong merupakan salah satu jenis pangan fermentasi traditional Indonesia (Barus dan Wijaya, 2011; Barus et al., 2013). Tape singkong merupakan hasil fermentasi singkong oleh ragi yang mengandung kapang, khamir, bakteri asam laktat, dan bakteri amilolitik (Khasanah dan Wikandari, 2014). Tape singkong memiliki kandungan protein 0,5 gram dalam setiap 100 gram bahan. Fermentasi tapai dapat meningkatkan kandungan Vitamin B1 (tiamina) hingga tiga kali lipat.Vitamin ini diperlukan oleh sistem saraf, sel otot, dan sistem pencernaan agar dapat berfungsi dengan baik.Karena mengandung berbagai macam bakteri "baik" yang aman dikonsumsi, tapai dapat digolongkan sebagai sumber probiotik bagi tubuh dan dapat mencegah terjadinya anemia, karena mikroorganisme yang berperan dalam fermentasinya mampu menghasilkan vitamin B12 (Nuraida dan Owens, 2014).

Tape singkong juga bisa dibuat aneka olahan produk makanan ringan, seperti dodol, keripik, dan cake. Makanan ringan berbahan baku dasar tape singkong, selain cake adalah dodol dan kerpik, juga mempunyai potensi yang sangat besar untuk dikembangkan. Dodol tape singkong merupakan makanan tradisional yang cukup populer di beberapa daerah di Indonesia, dapat diolah dari tepung ketan, tepung bijibijian, palawija maupun buah-buahan dicampur dengan gula atau diberitambahan bahan lain seperti tepung beras atau tepung ketan, tepung tapioka, tepung hunkwe, bahan pewarna maupun bahan lainnya. Cara pembuatan dodol sangat mudah, peralatan yang digunakan juga sederhana sehingga dapat diterapkan sebagai industri rumah tangga (Wahyuni et al., 2014; Novia et al, 2015; Utomo et al., 2016).

Permasalahan utama masyarakat di Desa Karanganyariadalah belum mengenal teknologi pengolahan tape singkong. Sebagian besar tape singkong di Desa Karanganyar hanya dijual dalam bentuk segardengan harga yang sangat murah (Rp. $6.000 / \mathrm{kg}$ ). Hal ini terjadi karena ketidak pahaman masayarakat setempat tentang jenis produk lain yang dapat dihasilkan dari bahan baku tape singkong, masyarakat juga belum memahami teknologi sederhana apa yang dapat diaplikasikan pada tape singkong yang mereka jual. Mereka beranggapan bahwa tape singkong hanya bisa jual dalam bentuk segar (belum diolah).Padahal hanya dengan sentuhan teknologi yang sederhana tape singkongdapat menjadi produk olahan yang bernilai tinggi dibandingkan dengan menjual dalam bentuk belum diolah. Salah satunya adalah mengolah tape singkong menjadi dodol, keripik, dan cake.

Permasalahan lainnya adalah lambannya akses informasi yang masuk kepedesaan dan kurangnya kepedulian masyarakat terhadap perkembangan teknologi membuat masyarakat ketinggalan informasi-informasi penting yang telah dan sedang berkembang, termasuk informasi penting mengenai teknologi tepat guna sederhana yang dapat diterapkan pada kehidupan sehari-hari. Selain itu tingkat pendidikan juga berpengaruh terhadap pola pikir kehidupan mayarakat sehingga kreasikreasi baru sulit mereka ciptakan dan dikembangkan.Sarana dan prasarana yang kurang, letak yang jauh dari kota juga merupakan suatu hambatan dalam penerimaan teknologi terbaru. Kenyataan inilah yang terjadi pada seluruh masyarakat 
pedesaan termasuk masyarakat desa Karanganyar Kecamatan Paiton, Kabupaten Probolinggo.

Permasalahan lainnya adalah peningkatan produksi bahan baku tape singkong pada saat panen raya sebesar 16,5-22 ton (10\%) dengan harga jual singkong Rp.1000,-/kg, sehingga harga tersebut lebih murah lagi dan sangat jauh dari harga normal. Kondisi tersebut memaksa para petani singkong untuk tetap menjual tape singkong dalam bentuk segar, karena terdesak oleh kebutuhan, bahkan ditemukan juga tape singkong yang tidak laku dijual dibuang percuma. Ditinjau dari aspek sosial budaya masyarakat setempat, banyaknya tape singkong yang tidak terjual atau terbuang sia-sia sangat dipengaruhi oleh kebiasaan dari pedagang pendahulunya, dan belum adanya sarana prasarana yang memadai dalam mengakses informasi secara cepat.

\section{BAHAN DAN METODE}

\section{Bahan}

Bahan aneka olahan tape singkong untuk keripik tape meliputi; tape singkong, tepung terigu, margarine, telur ayam, tepung sagu / tapioca, garam, soda kue, gula pasir, minyak goreng. Bahan baku pembuatan dodol tape sngkong, yaitu; tape singkong, tepung ketan, santan kental, gula, garam, margarine. Sedangkan bahan baku pembuatan cake tape singkong meliputi; tape singkong, tepung terigu, tepung maizena, gula, telur, SP, margarine, santan kental, dan keju / kismis /coco chips.

\section{Alat}

Alat yang digunakan adalah blender, gilingan mie (cetakan keripik), pemarut kelapa, sealer, dandang, kompor, pisau, talenan, sutil, bak penampungan bahan, wajan, sendok pengaduk, nampan cetakan, sepet, dan plastik kemasan.

\section{Metode / Pelaksanaan penelitian}

Metode pengumpulan data dilakukan dengan melakukan wawancara pada pengurus PKK dan masyarakat. Pengumpulan data ini dimaksudkan untuk mengetahui status sosial, pendidikan dan motivasi mitra kerja dalam kegiatan PKM yang dilaksanakan agar target luaran dapat tercapai.

Target luaran dinilai pada saat pelaksanaan kegiatan praktek pembuatan keripik dan dodol jagung afkir dan pemantauan keberlanjutan kegiatan dengan memanfatkan media soaial sebagai sarana promosi produk..

\section{HASIL DAN PEMBAHASAN}

Hasil pelaksanaan kegiatan Program Kemitraan Masyarakat melibatkan dua mitra. Mitra kerja yang ikut dalam kegiatan pelatihan pembuatan produksi dan pengemasan adalah 40 orang dengan distribusi pendidikan 10 orang Sarjana, 13 orang SMU, 8 orang SMP dan 9 orang SD. Secara umum, pendidikan mitra kerja cukup baik dan data yang ditemui menunjukkan bahwa tidak ada seorang pun dari peserta yang pernah mengetahui cara pembuatan keripik dan dodol tape singkong.

Rendahnya pengetahuan diversifikasi tape singkong mitra kerja dengan berlimpahnya bahan bakutape singkong di desa Karnganyar merupakan fenomena yang menarik perhatian tim kerja untuk melatih dan mentransfer pengetahuan pembuatan keripik dan dodol tape singkong. Tabel 1 memperlihatkan jumlah mitra kerja yang pernah membuat keripik dan dodol tape singkongsebelum kegiatan PKM dilaksanakan

Tabel 1.Mitra kerja yang pernah membuat keripik, dodol, dan cake dari tape singkong sebelum kegiatan PKM 


\begin{tabular}{lccc}
\hline & Keripik & Dodol & Cake \\
\hline Pernah & 0 & 0 & 0 \\
Belum pernah & 40 & 40 & 40 \\
Jumlah & 40 & 40 & 40 \\
\hline
\end{tabular}

Tabel 2. Produk yang dihasilkan menarik, dapat dikembangkan dan bernilai jual

\begin{tabular}{lccc}
\hline & Keripik & Dodol & Cake \\
\hline Ya & 40 & 39 & 40 \\
Tidak & 0 & 1 & 0 \\
Jumlah & 40 & 40 & 40 \\
\hline
\end{tabular}

Tabel 3. Bahan baku mudah diperoleh dan cara pembuatan produk mudah dibuat sendiri

\begin{tabular}{lccc}
\hline & Keripik & Dodol & Cake \\
\hline Ya & 40 & 40 & 40 \\
Tidak & 0 & 0 & 0 \\
Jumlah & 40 & 40 & 40 \\
\hline
\end{tabular}

Mitra kerja yang berjumlah 40 orang belum pernah membuat keripik, cake dan dodol tape singkong (Tabel 1). Setelah melaksanakan kegiatan, ternyata $100 \%$ mitra kerja dapat membuat produk keripik dan dodol tape singkong dengan baik yaitu secara fisik dan rasa keripik dan dodol menarik, sehingga dapat dikembangkan sebagai produk olahan dari tape singkong (Tabel 2). Kondisi produk akan lebih menarik dan ketahanan produk meningkat dengan dilakukan pengolahan dan pengemasan yang benar.

Peralatan pengemasan yang dimiliki mitra kerja menjadi modal penting dalam pengembangan produk dan peningkatan nilai jual keripik, cake dan dodol tape singkong. Dasar dalam pengembangan produk yaitu bahan dasar yaitu tape singkong sangat mudah didapatkan di desa Karanganyar. Produk keripik, cake dan dodol tape singkong juga relatif mudah di buat oleh mitra kerja pada saat pelatihan produksi (Tabel 3).
Kesimpulan dari kegiatan PKM yang telah dilakukan dapat disimpulkan bahwa:

1. Seluruh mitra kerja dapat membuat aneka olahan tape singkong serta melakukan pengemasan dengan baik.

2. Produk aneka olahan tape singkong yang dihasilkan pada pelatihan produksi menarik dan dapat dikembangkan.

3. Bahan dasar pembuatan produk aneka olahan tape singkong yang mudah didapatkan di desa Karanganyar.

\section{UCAPAN TERIMA KASIH}

Penulis mengucapkan terima kasih kepada seluruh pihak yang telah membantu dalam pelaksanaan kegiatan PKM dan seluruh pihak yang telah membantu dalam penelitian ini terutama kepada DPRM Dikti, Universitas Nurul Jadid, dan Kelompok Ibuibu PKK PKK RT.04/RW.02 dan RT. 17/RW.08 Desa Karanganyar Kabupaten Probolinggo.

\section{KESIMPULAN}

\section{DAFTAR PUSTAKA}

Barus, T., \& Wijaya, L.N. 2011.Mikrobiota dominan dan perannya dalam cita rasa 
"Tape" singkong. Journal of Biota. 16(2): 354-361.

Barus, T., Kristani, A., \& Yulandi, A. 2013. Diversity of amylase-producing bacillus spp. from "tape"(fermented cassava). Hayati Journal of Biosciences. 20(2): 94-98.

Hasanah, H., Jannah, A., \& Fasya, A.G. 2013. Pengaruh lama fermentasi terhadap kadar alkohol tape singkong (Manihot utilissima Pohl). Alchemy Journal of Chemistry. 2(1): 68-79.

Khasanah, N., \& Wikandari, P.R. 2014. Pengaruh lama fermentasi dan penambahan bakteri asam laktat lactobacillus plantarum b1765 terhadap mutu produk tape singkong. Jurnal Mahasiswa Teknologi Pendidikan. 3(1): 78-84.

Novia, C., Syaiful, \& Utomo, D. 2015. Diversifikasi mangga off grade menjadi selai dan dodol. Teknologi Pangan.7 (1): 60-65
Nuraida, L., \& Owens, J.D. 2014. Sweet, sour, alcoholic solid substrate fungal fermentations. Indigenous Fermented Foods of Southeast Asia. 137 (2): 5666.

Parwiroharsono. S. 2007. Potensi pengembangan industri dan bioekonomi berbasis makanan fermentasi tradisional. Jurnal Ilmu Kefarmasian Indonesia. 5(2):85-91.

Utomo, D., Murtadlo, K., \& Novia, C. 2016. Pemanfaaatan limbah biji nangka menjadi dodol dan kerupuk. Teknologi Pangan. 7 (3): 114-117.

Utomo, D., Wahyuni, R. \& Novia, C. 2014.Diversifikasi produk olahan apel manalagi kualitas afkir menjadi selai dan dodol. Jurnal Agrika. 8(2): 211217.

Wahyuni, R. Utomo, D., Novia, C. \& Syaiful. 2015. Peningkatan nilai ekonomis wortel kualitas afkir menjadi krupuk dan dodol. Cyber Techn. 9(2): 53-57. 